\title{
XENOTRANSPLANTATION, XENOZOONOSIS AND CONTEMPORARY IMAGININGS OF MONSTROSITY
}

\author{
Mary Murray
}

\begin{abstract}
This article looks at contemporary imaginings about monstrosity surrounding xenotransplantation and zoonosis. The impact of human to human organ transplantation on identity is considered, and provides context for consideration of possible effects of animal to human transplantation and zoonotic disease on human identity. The article looks at ways in which fears about monstrosity, xenotransplantation and zoonosis have been conjoined with ideas about the animal, feminine and racial other, and have pointed to social disruption and potential destabilisation of the body and self. The extent to which monstrous others may also destabilize binaries of identity and difference is also critically reflected upon.
\end{abstract}

\section{INTRODUCTION}

Monsters have been a persistent archetype in the human cultural imaginary and collective unconscious - populating myth, folklore, legend, religious belief, art, literature, and popular culture - throughout the world. The putative aetiology of monsters has included moral transgression such as bestiality, acts of god and demonic possession, as well as natural causes. The power of the human imagination has also figured as a causal factor in the creation of monsters. Historically it was believed that the ferocious power of the maternal imagination was capable of generating monstrous offspring. Such ideas have a long paternal and patriarchal pedigree, with a lineage that can be traced back to philosophers and scientists of classical antiquity including Aristotle and Hippocrates (Huet, 1993). In early modern Europe, too, stories about women giving birth to monsters as a result of the maternal imagination were widely circulated. It was thought that messages from the maternal imagination were transmitted through the medium of 'animal spirits' that coursed through the nervous system (Connor, 2004). Some women were reputed to have given 
birth to animal species such as frogs, snakes and lizards. Monstrous progeny included conjoined twins, hermaphrodites, and human-animal hybrids.

By the 19th century however, the scientific imagination, which many feminists regard as masculinised (Harding, 1986; Tauna, 1989; Adams, 1994) was engaged in the production of monsters through the science of teratogeny. Seeking to understand how monsters originate, the science of teratogeny produced, and continues to produce monstrosities in the laboratory (Greek \& Swingle Greek, 2000). Whilst teratogeny assumed the exclusion of the maternal imagination from the formation of the monster, the 'master discourse is that of the scientist in his laboratory, the modern womb. The scientist now takes the place of the mother' (Huet, 1993: 111). In more contemporary times, backed by mechanisms to ensure 'paternity' such as laws protecting intellectual property and patents, scientists have been developing a range of bio-technologies, including genetic modification and xenotransplantation, intended to prolong and save human life.

Xenotransplantation has a long history spanning several centuries (Deschamps, Roux, Sai, \& Gouin, 2005). In the last few decades of the late 2oth and early 21st century, xenotransplantation has been seen as offering a solution to the shortage of human organs, and as a way around the problem of having to secure consent to cadaveric donations or taking organs from live human donors (Somerville, 2000). In this paper, I will consider contemporary imaginings about monstrosity that have been provoked both by xenotransplantation and the infective risks of zoonosis that non-human animal to human transplantation may pose. To develop the argument the paper begins by considering the impact of human-to-human organ transplantation on personal identity. The paper then looks at the potential impact of xenotransplantation and zoonosis on human identity and fears that we may be in danger of making monsters of ourselves. In order to flesh this idea out I will also consider how ideas about the animal, the feminine and racial other have been entwined with fearful imaginings about zoonosis and xenotransplantation. The potency of monstrous imaginings surrounding xenotransplantation and zoonosis will be considered in terms of the potential of the monstrous to destabilize the internal order of the psyche as well as external social order and relationships. Some of the implications of such monstrous imaginings for tissue transfer will be touched on in the conclusion to the paper. 
Typically, people who adopt a 'spare parts' view of the body as independent of identity tend to distinguish body and self and do not view bodies as interdependent or inter-corporeal (Shaw, 2010). Transplant professionals may also reify organs that recipients receive, referring to them as muscles, pumps, filters, and bits of flesh. Psychiatric and psychological specialists too may consider it unnatural, if not pathological, for recipients to identify with their donors. However, research data suggests that the symbolic weight of the organ can profoundly effect a transformation of identity. In Change of Heart, Claire Sylvia (1997) gives an account of her experience of human to human organ transplantation, telling how she began to feel the presence of someone else in her when she received a new heart and lungs. Sociological (Fox \& Swazey, 1978) and anthropological research (Lock, 1995; Sharp, 1995) also shows that human to human organ transplantation can be personally transformative. Like Sylvia's (1997) personal account, ethnographic studies suggest that the transfer of organs from one human body to another has the potential to alter an organ recipient's definition of self in a significant way. An organ recipient's sense of self can extend to include the assumed emotional, moral or physical qualities of the organ donor.

The symbolic weight in Western culture of particular organs may have a particularly profound effect on identity transformation. In Western culture organs such as hearts and lungs are loaded with powerful metaphors that define what it means to be human and alive. Whilst the brain may be regarded as the seat of the self by people who adopt a 'spare parts' view of the body (Shaw, 2010), hearts have a long cultural and religious history as a symbol of the self or the soul, and lungs can symbolize the breath of life. Assumed independent or animate qualities of donated organs can engender positive feelings such as gentleness where a woman's heart has been received, or youth and strength where a young man's lungs have been received. For some recipients, the assumed animate and independent qualities of organs can also be a source of fear (Sharp, 1995) and anxiety (Sylvia, 1997). Organ recipients can also experience a reconstruction or transformation of themselves that may include incorporating some essence of the dead organ donor. Meanwhile an organ donors' kin may assert the existence of an extended self, and kin may be persuaded to donate a relative's organs in the belief that the dead person or their life essence can 'live on' in another body. Indeed, a wish to establish and extend links of fictive kinship with the organ recipient may be expressed. Moreover, organ recipients may develop a sense of community with the organ donor, and express a desire to reciprocate in some way, particularly if they have received life saving organs. 
Xenotransplantation involves any procedure in which nonhuman animals cells, tissues or organs are transplanted into the human body. Xenotransplantation has involved many different species of animals and a variety of primates. Primates are no longer considered as potential 'donors' because of risks of disease transmission (Deschamps et al., 2005). In comparison to other species, the rate of reproduction among primates is low, their population numbers are low and international trade in chimpanzees is banned. Currently there is, effectively, a worldwide moratorium preventing the use of primates for xenotransplantation (O’Neill, 2006). Today, pigs are the preferred species for xenotransplantation. Unlike primates, pigs are genetically and immunologically more distant from humans. However, pigs and humans are anatomically and physiologically quite similar. Pigs also reproduce rapidly. Moreover, since the 1990s, transgenic pigs carrying human genes have been produced. The purpose of genetically engineering pigs in this way is to try and help prevent rejection of animal organs by the human immune system (Deschamps et al., 2005; O'Neill, 2006). Although previous attempts to use animal organs as replacements for human organs have been unsuccessful, genetically engineered pigs, (carrying human genes), are regarded as a future source of organs for transplanting into humans. Meanwhile, porcine pancreatic islet cells are being used as a treatment for Type 1 Diabetes, and porcine fetal brain cells can be used to treat Parkinson's disease. Pig valves can also be used to replace human heart valves.

Research has revealed quite a high level of public acceptance of xenotransplantation (Lundin \& Idvall, 2003; De Bona, Canova, Rumiati, Russo, \& Ermani, 2004; Hagelin, 2004; Wright, 2004). A study in Australia found that over two thirds of Australians would accept an animal organ to save their own life (Edminstone, 2004). Lundin's (1999) study of diabetics who had received animal cells also confirms pragmatic views, where issues of life and death for the human recipient may take precedence over existential or ethical doubts about the use of animals for transplantation. As one respondent in Lundin's study said, 'I think I could do anything because I don't want to die. That's the last thing I want to do' (1999: 8).

However, during the 1980's, strong feelings were aroused when a newborn girl, 'Baby Fae', was given a baboon heart. The child survived for twenty days, during which time there was a massive protest action. In a television interview the child's mother said she wondered how her daughter would be affected by having an animal organ in her body (Panorama, 1996). Considerable opposition to xenotransplantation was found in a UK survey underwritten by 
the Wellcome Trust, the world's largest medical research charity. Respondents ranked xenotransplantation as the least preferred way out of nine possible options of dealing with the shortage of organs (Warren, 2004). Likewise, a study in Greece found that artificial organs were preferred over animal organs, especially genetically modified ones (Papagaroufali, 1996).

Lundin's (1999) research points to some of the anxiety-provoking potential of xeno technology. One respondent in the study eschewed the possibility that something animal, such as their feelings or 'spirit' might be integrated into the human body and psyche as a result of xenotransplantation on the grounds that '....animals can't think and work out things... I don't feel they can feel pleasure the way we do... animals are not personal they mostly follow instincts' (1999:21). Lundin also found that most respondents assumed the existence of a biological memory function, and stated that when organs, and especially porcine islets are inserted into the body 'my informants feel that something uncontrollable has been released, something that can be pumped through the whole blood system to build up, break down, or otherwise change their bodies' (1999:17). The diffuse nature of islet cells can appear particularly unpredictable and menacing, and all of the patients in Lundin's study thought it important to know if the islets were still in their bodies or had just disappeared, perhaps being rinsed out in urine (1999:16). Though the space taken up by animal organs may be similar to that of human organs, in emotional terms animal organs may be perceived as filling the body in a different way. Again, Lundin's respondents regarded an animal organ differently to an organ donated by a relative as 'something meaty and big - I don't know what' (1999:14), with the potential to influence a person in an unpredictable way.

Cultural and religious ideas about impurity may also affect attitudes towards xenotransplantation. The daughter of one of Lundin's research respondents was reported as being dubious about xenotransplantation. As the research respondent put it: 'she thought it was a bit disgusting. Pigs are filthy animals, and you can't have that in your body' (1999:8). In a television documentary about animal transplants a Jewish woman whose husband had Parkinson's disease said she found it repugnant that her husband had porcine fetal cells transplanted into his brain (Panorama, 1996). Similarly, in a study of kidney patients on the waiting list for transplantation, two of the patients who said they would never accept a xenotransplant explained that this was because of their Muslim religious beliefs (Kranenburg, Kerssens, Ijzermans, Weimar, \& Busschbach, 2005).

Given the symbolic significance of human organs for self-identity, part of the 
concern about the transplantation of animal organs into humans may be to do with a perception that it challenges the boundary that has been drawn between humans and other animals in modern society in a way that puts us in danger of making animals of ourselves (Murray, 2006, 2007). For instance, in a European study of the opinions of children and young adults towards transgenic animals and xeno technology, statements such as, 'That's disgusting - who would want a pig's heart!!' were made (Levitt, 1996). A contributor to the Nuffield Council consultation process (an independent body that examines and reports on ethical issues in medicine and biology) about xenotransplantation, expressed the view that humans have been made superior to animals and that it would be degrading to be made part pig, part human' (Nuffield Council on Bioethics, 1996:105). In response to the first transgenic organ transplant scheduled to go ahead in England in 1996, a potential organ recipient said, 'No, I don't want a pig's kidney... I wouldn't feel safe. I'd rather die than live half-human and half-animal' (Lundin, 1999:19). Another man said, 'I would never have a pig's kidney inside me. I want to go to my grave as a human being, not half-human, half-pig' (Boyle, 1989:20). It would seem then, that for some people at least, xenotransplantation conjures up images of human-animal hybridity which they find disturbing.

Human-animal hybrids have had an abiding and ubiquitous presence in the collective unconscious and cultural imaginary (Allan, 2008; Borges, 1984; Guirand, 1970). In late modernity, however, xenotransplantation and contemporary developments in bio-technology deliver us a lot closer to human-animal hybridity and monstrosity than mythical images of metamorphoses. In recent years, science has produced a range of animal-human hybrids (Mikkelson, 2006) and animals including cows and pigs have been genetically modified with human genes. Perhaps one of the most arresting images of human-animal hybridity in recent times has been that of the mouse with what appeared to be a human ear grafted onto its back. The mouse became an iconic reference through which people expressed differing and highly contested views on bioscience (Brown, 2006). Xenotransplantation, too, provokes varied and often competing interpretations including hope, awe, fear, and disgust, and - like the mouse - may fascinate and disturb as it alludes to human animal hybridity.

\section{IMAGINING MONSTERS}

The human animal hybrid has also been linked to the archetype of monstrosity in the cultural imaginary and collective unconscious. Examples include the 16th century Monster of Cracow hybridizing human, ape, dog, toad and cat, and the Monster of Ravena hybridizing human, mammal, reptile, fish and bird, 
with an ambiguous sexual identity (Shildrick, 2002). Shildrick observes that what is monstrous about monsters is most often their form of embodiment, specifically, an aberrant corporeality. She postulates that the linkage between monstrous others, whether those of human birth or human made creations, is often perceived to be an 'unnatural' and potentially transgressive hybrid corporeality.

As xenotransplantation activates ambiguities and anxieties about the 'animal within', contemporary imaginings about xenotransplantation point to possibilities of monstrous metamorphoses. As Woods puts it: 'Xenotransplantation breaches the boundaries of the body with animal organs, kindling a human imagination entranced with the monstrousness of human-animal anomalies' (1998:53). When asked about the use of genetically engineered animals in organ transplantation, one research respondent, in horror, expressed the view that 'the last thing I want in this short life of mine is to have a monster inside me, perhaps become one... these are not natural things...' (Papagaroufali, 1996:249).

Whilst a European study of the opinions of young adults and children found broad support for transgenic and xenograft technology (Levitt, 1996), the study also pointed to ambivalence and confusion about boundary blurring, including the view that genetic modification of pigs would turn them into people and that we would be creating a monster (Levitt, 1996). Woods (1998) suggests that the full potency of such imaginings may, like zoonosis, only emerge during the clinical process when animal organs or zoonotic disease take up residence in the human body.

\section{MONSTROUS CONTAGION}

Zoonosis refers to any disease that can be transmitted to humans from animals. Examples include plague from rats, rabies from dogs, and Ebola from monkeys. Zoonotic risks may also be associated with xenotransplantation. Particular concerns have been expressed about porcine endogenous retroviruses (PERV) being transmitted from pigs to humans through organ transplantation (Takeuchi, 200o). Perceived risks have led to calls for more data and research, regulations, strict guidelines and control, as well as international moratoriums on xenotransplantation (O’Neill, 2006).

Knowledge of infective risks of xenotransplantation has also been found to influence the acceptability of the technology. Amongst those waiting for transplants, $67 \%$ of respondents in one study said they would accept an ani- 
mal organ if necessary. However, when provided with information about the presumed waiting time, presumed quality of the organ, and infective risks of xenotransplantation, the percentage of those willing to accept an animal organ dropped to $54 \%$. The study was conducted in 2002 and 2003 when epidemics of classical 'swine fever' and 'mad cow disease' received considerable media coverage (Kranenburg, Kerssens, Ijzermans, Weimar \& Busschbach, 2005). In a study about porcine islet xenotransplantation, $52 \%$ of patients said they would accept porcine islets. When told of potential risks of porcine islet transplantation, including disease transmission, $70.5 \%$ of patients said they would not accept the technology (Deschamps, Roux, Gouin, \& Sai, 2005).

Fears about xenozoonosis have been animated by, and are arguably part of a late 2oth, and early 21 st century form of zoonotic mysophobia; that is, excessive anxiety caused by imagined or real risks of contamination from animals. Zoonotic anxiety and fear has been orchestrated by dramatic news media coverage. Casting itself in the role of oracle and prophet of doom, the media has foretold the potential, (if not likely), deadly consequences of widespread infection and pandemics from a range of zoonotic diseases including HIV and AIDS, SARs, 'Mad Cow Disease,' 'Bird Flu', and, most recently, 'Swine Flu'. The в ВC (2005) reported that Bird Flu could kill 150 million people. The UK based Metro (2005) reported that, according to the World Health Organization, the outbreak of swine flu was 'a public health event of international concern', and that, according to some experts, swine flu might develop into a pandemic that could kill 120 million people. In 2005, the New Zealand Manawatu Standard, a daily newspaper published in a small city of about 80,000 inhabitants, with a wider readership in the lower north island of New Zealand, front-paged a story with the headline 'Region bracing for bird flu', predicting 26,000 people infected, 5,000 deaths in the city and problems dealing with the storage of corpses (Brown, 2005). In the same year, the front cover of Mike Davis's (2005) book, The Monster At Our Door: The Global Threat Of Avian Flu, resembled a gothic horror genre, the monster slot being filled semiotically by a picture of a beady-eyed rooster sporting a threatening red cockscomb (Shukin, 2009:218).

Zoonotic anxieties may express more than a concern about catching infectious diseases: To what extent might disturbing images of human animal hybridity and monstrous metamorphoses also be embedded in contemporary fears about zoonosis, including disease that could be transmitted to humans through xenotransplantation? Illnesses that are the most terrifying are perceived not only as lethal but also dehumanizing (Sontag, 1991). During the 19th century, the fear of rabies was accompanied by the fantasy that contamination by animals transformed people into maddened animals. Kete (1994) similarly 
observes that as it unfolded in the imagination of nineteenth century France, rabies had the power to transform a human being into a dangerous and uncontrollable beast. As was the case with Jekyll and Hyde, in the phobic imagination of the nineteenth century, the rabies victims would remain conscious of their monstrosity.

Monsters are deeply disturbing because of their perceived potential to disrupt both the 'internal' order of the psyche and the 'external' order of society. The specter of monstrous metamorphosis challenges the Cartesian view of the person as a rational self possessed individual with a unified identity as it also points to the possibility of wider patterns of social relationships and social organization becoming destabilized. According to Takeuchi, '... if such infections spread to patients' contacts and the wider human community, the public health risk and ensuing economic impact could outweigh benefits to individual patients and profits expected by the medical/pharmaceutical industry' (2000:2698).

Whilst there clearly is a scientific basis for concerns about zoonosis, it is also clear that concerns about zoonosis in the late 2oth and early 21st centuries have been expressed through a discourse of alterity, conjoining ideas about animal, ethnic, female and monstrous others. This suggests that there may be linkages between zoonotic anxieties and some of the ordered, but increasingly contested, patterns of social relationships that late modern societies have been constructed in and through. These relationships have included speciesism - beliefs and practices which enable humans to allow their interests to take precedence over the interests of other species (Singer, 1995) - racism, and gender divisions.

Speciesism, racism, and gendered relationships have been entwined with a process of conceptual and geographical othering. Part of the imaginative geography' (Said, 1978) of modernity has involved a positioning of animals in relation to humans in a way that combines geographical othering with conceptual othering. In modern and late modern societies, millions of animals are assigned to places and spaces that are different to the places and spaces that humans are located in. In modern and late modern western societies, a geography of space and place has shaped the human encounter with other species. Animals have been classified as wild animals, laboratory animals, zoo animals, farm animals and domestic pets. Apart from companion animals and perhaps free range, family farmed animals or back yard chickens, the place and space of non-human animals has usually been different and other to the space and place of human animals. In terms of factory farmed animals such as chickens and pigs, modern and late modern agricultural practices are such that it is 
unusual for such animals to get 'out of place'. From birth to death, the lives of these animals are spatially ordered and controlled.

A combination of conceptual and geographical othering has also upheld discriminatory beliefs and practices based on ethnicity, 'race', and gender. Ideologies, discourses and practices around ethnicity, 'race' and gender in modern and late modern western societies have frequently resulted in spacial separations of different groups of humans. As nation states have imposed immigration controls, apartheid and segregation, ghettoization has been a frequent outcome of discriminatory practices based on 'race' (Giddens, 1997). There has also been a tendency to regard mixed racial marriages as taboo. In this respect, racial 'others' may be perceived as being out of place, 'polluting' private sphere space of family and home. Ideologies, discourses and practices about femininity in modern western societies have also located women and men in different social spaces and places. Even today, there is a strong association between women and the private domestic sphere of home and family. Whilst women now also participate extensively in public sphere activities once deemed to be the preserve of men, it is still assumed that 'respectable' women are less likely to be found in some of the more dangerous and unsavory places of public sphere space.

Over the last few decades, nightmare scenarios have been presented in the media about the monstrous impact that a range of zoonotic diseases might have on human society. Apocalyptic doomsday visions of zoonotic pandemics affecting the entire fabric of society have been revealed. Negative impacts on food supply and infrastructure resources such as water, electricity, fuel and national and international economies have been foretold, leading to national and international social collapse. Projections about the colossal loss of human life that could be involved have also conjured up fears about the survival of the human species. Sontag (1991) has pointed to ways in which language used to describe potentially deadly disease is often that of invasion, and that epidemic diseases have often elicited calls to ban the entry of foreigners; and xenophobic propaganda has depicted immigrants as the bearers of disease (including cholera, yellow fever, typhoid fever and tuberculosis) in the late 19th century. Contemporary fears and anxieties expressed in the media, and amongst research participants, suggest that in late modern society, the diseases with the monstrous power to invade human societies, threatening the survival of the human race or species, are perceived to be those which dangerously entwine the animal and ethnic other.

In the 1980's and 1990's 'Mad Cow Disease' hit the headlines. A widely accepted 
scientific view was that the disease was caused by 'animal cannibalism' (Shukin, 2009). In Britain, cattle, who are herbivores rather than carnivores by nature, were given food made from sheep offal infected with the neurological disease scrapie. Scrapie was passed on to the cattle, and those that developed bovine spongioform encephalitis (BSE) died (Somerville, 200o). In some cases, people who ate meat from infected animals developed variant Creutzfeldt - Jakob disease (vCJD), commonly referred to as Mad Cow Disease (Somerville, 2000). The extent of vCJD is still not known (Somerville, 2000). In 2005, British scientists Colchester and Colchester, (2005) published an article in the Lancet tracing the emergence of Mad Cow disease in the UK back to bone collectors in India. The Colchesters speculated that infected corpses floating in the River Ganges after Hindu funerals carried the human version of Mad Cow disease. They hypothesized that the infected cadavers were mixed with the flesh and bones of animals exported to Britain between the 1950's and 1970's. Shukin (2009) sees the two scientific views of Mad Cow disease as asserting biological boundaries of 'species' and 'race', and the Colchester's origin story of Mad Cow disease as a metaphor for the infection of Europe by ethnic others.

When the HIV and AIDS epidemic began to hit the headlines in Europe and America during the 1980's, subliminal connections to the 'dark continent' and an animal past were stirred (Sontag, 1991), and HIv has recently been declared to be of animal origin (Shukin, 2009). The 2003 SARS epidemic, which affected a number of cities across the world, was thought to be the result of a speciesleaping virus. The virus was carried by civet cats, considered by many Chinese people to be a gastronomic delicacy (Shukin, 2009: 206). 2003 also brought the outbreak of a deadly strain of bird flu in China. As bird flu spread throughout Asian countries, the Middle East, Africa and Europe, racist stereotypes were upheld by media depictions of unhygienic and cruel practices in Asian food markets (Murray, 2008). Excessive inter-species intimacy and intermingling of animal and human flesh in Asian food markets, was 'racially pathologized as zoonotic hotbeds of pandemic discourse' (Shukin, 2009: 209). According to a 2005 article in Newsweek, the monstrous specter of human-to-human transmission of bird flu would likely originate '...in China. The place is home to 1.3 billion humans - three quarters of them still living on the farm - and more than 10 times that number of chickens, ducks, and other domestic poultry...' (Liu, 2005). According to the same article 'Those (Chinese) farmers keep 70 per cent of the world's pigs, which can be walking dishes for mutating strains of flu...' (Liu, 2005).

A few years later, it was reported in the media that patient zero in the swine flu epidemic was Mexican (The Wall Street Journal, 2009). Although the geo- 
graphic origin of swine flu is uncertain, a child in the Mexican town of La Gloria is the earliest known survivor of 2009 H1N1. According to an article in Nature News, swine flu spread from Mexico to the UsA and beyond (Butler, 2009). Airing connections between infectious diseases and quarantining different sections of the population, countries or immigrants, Tinker-Salas (2009) suggested that media focus on Mexico as ground zero in the swine flu pandemic might induce its own harmful symptoms, namely scapegoating, xenophobia and racism. Immigrants might not only be undocumented, they might also be regarded as unhealthy purveyors of illness.

Residents of La Gloria associated their illness with the proximity of huge pig farms run by the world's largest pork producer, the US company Smithfield. Pigs were fed on genetically modified maize imported from the Usa mixed with the ground up remains of chicken, a practice thought to be safe even if chickens are infected with bird flu, providing sterilization occurs at a very high temperature. Villagers complained about the stench and worried that their water supply had become contaminated from pig excrement scattered on fields. While Smithfield's maintained that there was no evidence of swine flu in the herd and employees tested negative for the virus (Television Suisse Romanda, 2009), in 2008 the Pew Commission produced a study in which the commissioners concluded that industrial scale farm animal production poses an unacceptable risk to the public. The commission concluded that the close confines of modern feed and animal management methods led to an increased pathogen risk and magnified opportunities for transmission from animals to humans. Similarly, Greger (2006) argues that stressful, overcrowded confinement in industrial poultry farms facilitates immune suppression in birds already bred with weakened immunity, offering viruses like bird flu ample opportunities for spread, amplification, and mutation.

In the past, it was believed that monsters lived in remote places, particularly uncharted parts of the world. According to Asma (2009), such beliefs encouraged community cohesion and fostered xenophobia. The Greeks and Romans thought that people in distant lands were barbarians. This prejudice was confirmed by the belief that barbarian people lived amongst monsters, and that some foreigners were, themselves, monsters (Asma, 2009). Modern and late modern fixations on infective risks of zoonotic disease, embedded in a discourse of alterity, conjoining the animal, ethnic and monstrous other, seem to express a fear that monstrous others may be a lot closer to home than in past times. Contemporary imaginings about the monstrous proportions of zoonotic disease have included the destabilization and destruction of social relationships and structures in the public sphere, as they have raised the specter 
of the monster within.

THE MONSTER WITHIN

In modernity, human bodies are often portrayed, and perhaps experienced, as being delineated and separate from other bodies and the environment. According to Bahktin (1968), in modern western societies the body is regarded as being 'closed' and does not merge with other bodies and the environment. The body is regarded as an individual possession over which the sovereign self with a unified identity is encouraged to exercise rational control and discipline. This view of the body is of course contestable, both at the level of ideology and discourse and in terms of the phenomenology of lived experience. According to this perspective, the idea of bodily closure and separation pertains to an ideal of masculine bodily integrity, and contrasts with the anomalous female 'leaky' body, and female pregnant body which blur the boundaries of self and other. In the absence of lactation, menstruation and pregnancy, male bodies do not display the same degree or kinds of seepage as women's bodies. Phenomenologically, a more closed body may be experienced as a container for and signify a more individuated ego identity with more defined distinctions between self and other. In contrast, the exchange of life supporting fluids from mother to child through the pregnant and maternal body demonstrates the interdependence and relational nature of all bodies.

As Creed (1993) observes this ability to give birth links women to the animal world and lends credence to the idea that in her mothering role, woman is transformed into a human-animal figure, a hybrid amalgam of different species. Perhaps unsurprisingly then, women and monsters have often been conflated. In the late 19th and early 20 th centuries, for example, ideas about the feminine, the racial other, the animal other, and the monstrous were intertwined. Women were perceived as having potentially monstrous sexual and maternal appetites, capable of undermining racial purity and thus white civilized society. Both women and non-white 'races' were also perceived as capable of undermining white civilization by feeding off the bodily as well as economic resources of white men (Shildrick, 2002). Fears about the degeneration of humanity into lower forms of life from our animal past were a constant background threat. Women were widely represented in popular culture as predatory animals such as vampires with monstrous appetites capable of draining the life force from their victims. Imaginings about women's excessive maternal and sexual desires were also represented in images of women turning into animals such as wolves, black panthers and gorillas (Shildrick, 2002). Like animals, women were thought to be closer to nature than men. Like animals, women were also 
thought to be irrational and not fully agents of their own will, with bodies feared to be uncontrollable, uncontainable, and unpredictable.

Human to human organ transplantation, and hybrid and monstrous imaginings about xenotransplantation render unstable the masculinist idea of closed bodily integrity, and the modernist view that identity is located within an individual bounded self with a unified identity and a unique personality. While some organ recipients may regard the body and self as phenomenally separate and distinct, other people seem to be saying that their bodies have, or could become, an amalgam of 'self' and 'other' (Locke, 1995). For these people, human to human organ transplantation and imaginings about xenotransplantation show that embodiment can be significant to definitions of identity, because it is through the body that we experience the world. Anxious and fearful imaginings about xenotransplantation speak not only to possible encounters with the 'other' animal within, but also to the possibility of the monstrous other within.

The more we believe that we can control our bodies the more anxious we may become with evidence of the vulnerability of our bodies. If the body is at risk, the stability of the self is threatened, as Shildrick (2002) says, due to the fact that corporeal and ontological anxiety is inextricably entwined. Sontag's (1991) observations about ways in which the metaphors and mythology of disease constructs particular identities illustrate this: Diseases such as tuberculosis, syphilis, cancer and AIDs, for example, have been linked to particular personality types with distinct moral characteristics. Moreover, embedded in the discourse around HIV and AIDS, was a perception of an alien and engulfing other with the power to disintegrate the 'closed' singular self (Shildrick, 2002). Anxieties about xenotransplantation and zoonosis may echo and amplify such perceptions. Whilst it was long thought that the species barrier was insurmountable, it appears that the monstrous is no respecter of boundaries. Not only is the monstrous body perceived as deviant, as Shildrick (2002) observes, it is also perceived as contagious and capable of spreading its own identity confusion. A perceived risk of xenotransplantation, for instance, is infection by porcine retroviruses.

Monsters are frightening because they are what Freud (2003) would call the 'uncanny'; that is, something which is frightening because it awakens a memory or reminds us of something that has been well known from long or close association. Monsters haunt us because they stir an inner recognition of openness and vulnerability. Imaginings of animal human hybrid monsters may also remind us of our animal nature. All of this disturbs modern western ideas about the bounded body and unique individual self, as well as ideas about the 
integrity of the human species. Genetically modified animals and organs carrying human genes allude to the anxiety-provoking double that Freud identified as arousing dread and creeping horror.

\section{CONCLUSION}

Bio-technologies such as genetic modification and xenotransplantation have provoked moral objections as they have stirred contemporary imaginings of monstrosity. In this article, I have explored ways in which ideas about the animal, racial and feminine other can be entwined in such imaginings. I have suggested that there may be linkages between monstrous imaginings about xenotransplantation and xenozoonosis and some of the ordered, but increasingly contested, patterns of social relationships through which late modern societies have been constructed. Anxieties about xenotransplantation and xenozoonosis have been embedded in discourses that have conjoined conceptual and geographical othering of species, race and gender. Monstrous imaginings have expressed anxieties about 'other' potentially dangerous and polluting species and races getting 'out of place. Organ transplantation also challenges the masculinist idea of closed bodily integrity and a unified self. Gothic fears about xeno metamorphoses conjure up the possibility that like animals and women, our bodies could become uncontainable, uncontrollable and unpredictable, and that we may not be fully agents of our own will.

Moral objections about bio-technologies such as genetic modification and xenotransplantation include religious and cultural ideas about pollution. Whilst many scientists claim that the idea of firm divisions among species is out of date and in principle there is no reason that species characteristics cannot be interchangeable, the importance of species integrity and what is perceived to be natural is upheld by others (Midgley, 200o). Animal rights advocates, too, regard the science involved in bio-technologies, such as xenotransplantation, as morally unacceptable because of the suffering inflicted on countless animals in the development of such technologies (Uncaged Campaigns, 2011).

Cultural theorists, though, have been heartened by perceived utopian intimations of monsters. Donna Haraway (2004), for example, views transgressive boundary blurring hybrid animals as a challenge to the anthropocentric humanist subject. Shildrick (2002), too, sides with monsters as they signify the radical destabilization of binary processes of difference and identity that devalue otherness. However, celebrations of this kind may serve to occlude the enormous suffering endured by animals caught up in bio-technologies such as xenotransplantation and genetic engineering capable of creating hybrids and 
'monsters. Welcoming hybrid animals and monsters on the grounds that they challenge the anthropocentric humanist subject and destabilize difference and otherness, whilst potentially affirmative, may occlude the fact that the creation of such beings has been predicated on speciesist binaries and social structures. Indeed, such occlusion may serve to perpetuate rather than transcend such systems.

It is possible that imaginings about the animal within may provoke us to question the ethics of practices such as xenotransplantation and genetic modification. However, as Shaw (personal communication, June 2011) points out, encouraged by medicine and science, many people in modern and late modern societies refuse to accept the vulnerability of our embodiment and our mortality. Organ transplantation may be regarded as an attempt to deny vulnerability by 'cheating' death and extending life by technological means. The success of this quest relies on the incorporation of the 'alien' who is not meant to be acknowledged. This can be achieved immunologically, by way of anti-rejection drugs, and psychically, through denial. To effect this, organ recipients may hold, or be encouraged to adopt, an instrumental 'spare parts' view of the body and its organs. In an attempt to offset monstrous imaginings about xenotransplantation, it is perhaps more likely that animal, as well as human organs, will be increasingly reified and commodified by transplant professionals, psychological specialists and organ recipients. The possibility that organs may embody and carry an essence of the dead animal or human may be increasingly dismissed as 'magical thinking' in favor of an objectified 'thing-like' scientific medical view of animal and human organs. It is likely that this would serve to deepen the ethical invisibility of the non-human animal and perpetuate the social relationships that construct this invisibility and enable bio-technologies such as xenotransplantation.

\section{ACKNOWLEDGMENTS}

I would like to thank Rhonda Shaw and an anonymous referee for constructive comments on earlier versions of this paper.

\section{REFERENCES}

Adams, C.J. 1994 Neither Man nor Beast: Feminism and the Defense of Animals. New York: Continuum.

Asma, S.T. 2009 On Monsters: An Unnatural History of Our Worst Fears. Oxford: Oxford University Press. 
Bahktin, M. 1968 Rabelais and His World. Cambridge: MIT Press.

ввС News. 2005, 30th September, Bird flu could kill 150 million people. Retrieved June 8, 2011 from http://news.bbc.co.uk/2/hi/asia-pacific/4292426.stm.

Boyle, J. 1989 'Using animals for transplant organs', Bulletin of Medical Ethics, 51:20-22.

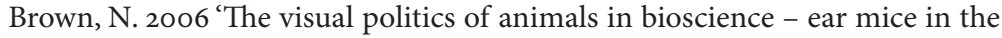
public sphere', Xenotransplantation, 13(6):501-505

Brown, S. 2005 'Region bracing for bird flu', Manawatu Standard, Palmerston North, New Zealand.

Butler, D. 2009 'Swine flu outbreak sweeps the globe' Nature News. Retrieved July 13, 2011 from http://www.nature.com.

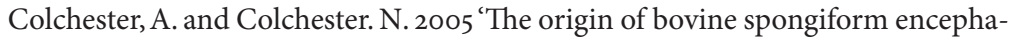
lopathy: The human prion disease hypothesis', Lancet, 366, 9488:859.

Connor, S. 2004 The Book of Skin. London: Reaktion Books.

Creed, B. 1993 The Monstrous Feminine: Film, Feminism, Psychoanalysis, New York: Routledge.

Davis, M. 2005 The Monster At Our Door: The Global Threat of Avian Flu, New York: New Press.

De Bona, M., Canova, D., Rumiati, R., Russo, F.P., and Ermani, M. 2004 'Understanding of and attitudes to xenotransplantation: A survey among Italian university students'. Xenotransplantation, 11:133-140.

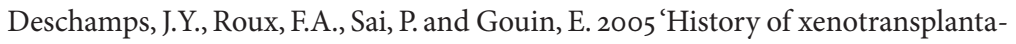
tion', Xenotransplantation, 12(2): 91-109.

Deschamps, J.Y., Roux, F.A., Gouin, E., \& Sai, P. 2005 'Reluctance of French patients with type 1 diabetes to undergo pig pancreatic islet transplantation', Xenotransplantation, 12(3):175-180.

Edminstone, L. 2004 'Aussies fine with animal organ transplants'. The Courier-Mail, August 23:3 
Freud, S. 2003 The Uncanny. Trans. David McClintock, London: Penguin.

Giddens, A. 1997 Sociology (3rd ed). Cambridge: Polity Press.

Greek, R. and Swingle Greek, J. 2000 Sacred Cows and Golden Geese: The Human Cost of Experiments on Animals. New York \& London: Continuum International.

Greger, M. 2006 Bird Flu: A Virus Of Our Own Hatching. New York: Lantern Books.

Hagelin, J. 2004 'Public opinion surveys about xenotransplantation', Xenotransplantation, 11:551-558.

Harding, S. 1986 The Science Question in Feminism. New York: Cornell University Press.

Haraway, D. 2004 'The promises of monsters: A regenerative politics for inappropriate/d others', in The Haraway Reader, New York: Routledge: 63124

Huet, M.H. 1993 Monstrous Imagination. Cambridge, Massachusetts: Harvard University Press.

Jones, O. 2000 'Unethical geographies of human-non-human relations: encounters, collectives and spaces', in C. Philo and C. Wilbert (eds) Animal Spaces, Beastly Places: New geographies of human-animal relations. London: Routledge: $268-291$.

Kete, K. 1994 The Beast in the Boudoir: Pet keeping in nineteenth-century Paris. Berkeley: University of California Press.

Kranenburg, L. W., Kerssens, C., Ijzermans, W.Z., Weimar, W., \& Busschbach, J.J.V. 2005 'Reluctant acceptance of xenotransplantation in kidney patients on a waiting list for transplantation', Social Science \& Medicine, 61:1828-1834.

Levitt, M.1996. Astrid the 'pig with the human heart': Should the Research go on? University of Central Lancashire: The Biocult Project.

Liu, M. 2005 'The flimsy wall of China', Newsweek, October 31:41. 


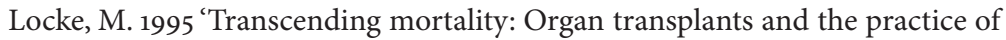
contradictions', Medical Anthropology Quarterly, 9(3):390-393.

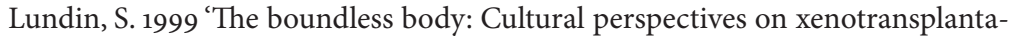
tion', Ethnos, 64(1):5-31.

Lundin, S., and Idvall, M. 2003 'Attitudes of Swedes to marginal donors and xenotransplantation', Journal of Medical Ethics, 29:186-192

Metro, 2009 Swine flu 'could kill up to 120 m'. Retrieved June 8, 2011, from http:// www.metro.co.uk/news/635961-swine-flu-could-kill-up-to-12om.

Midgley, M. 2000 Biotechnology and Monstrosity: Why We Should Pay Attention to the 'Yuk Factor', Hastings Center Report, September-October:7-15.

Mikkelson, T.R. 2006 'Man or mouse? The Danish Council of Ethics'. Retrieved June 8, 2001 from http://etiskraad.dk/upload/publications-en/stem-cellresearch/man-or-mouse/kapo6.htm

Murray, M. 2004 'Beasts, boundaries, zoonosis and monstrosity', International Journal of the Humanities, 2(3):2577-2581.

Murray, M. 2006 'Lazarus, liminality, and animality: xenotransplantation, zoonosis, and the space and place of humans and animals in late modern society', Mortality, 11(1):45-56.

Murray, M. 2007 'Xenotransplantation and the post-human future' in M. Sque and S. Payne (eds) Organ and Tissue Donation: An Evidence Base for Practice. Maidenhead and New York: Open University Press:152-168.

Murray, M. 2008 Feathers and Fear: Bird Flu, the Environment and the 'Other'. Sociology of the Environment Conference, Beijing: Renmin University of China.

Nuffield Council on Bioethics.1996 Animal to Human Transplants: The Ethics of Xenotransplantation. London: Nuffield Council on Bioethics.

O’Neill, R.D. 2006 'Xenotransplantation: the solution to the shortage of human organs for transplantation?', Mortality, 11(2):211-231. 
Panorama. 1996 'Animal transplants', (documentary).U.K. British Broadcasting Corporation.

Papagaroufali, E. 1996 'Xenotransplantation and trangenesis: Im-moral stories about human-animals relations in the West' in P. Descola and G. Palsson (eds). Nature and Society: Anthropological Perspectives, London: Routledge: $240-255$

Pew Commission. 2008 Putting meat on the table: Industrial farm animal production in America: A Report of the Pew Commission on Industrial Farm Animal Production. Retrieved 12th July, 2011, from http://www.ncifap.org/ bin/e/j/PCFAPin.pdf

Said, E. 1978 Orientalism. London: Routledge \& Kegan Paul.

Shaw, R. 2010 'Organ donation in Aotearoa/New Zealand: Cultural phenomenology and moral humility', Body \& Society, 16(3):127-147.

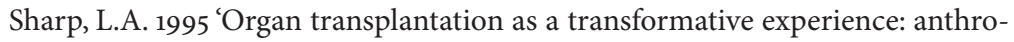
pological insights into the restructuring of the self', Medical Anthropological Quarterly, 9(3):357-389.

Shildrick, M. 2002 Embodying the Monster: Encounters with the Vulnerable Self. London: Sage.

Shukin, N. 2009 Animal Capital: Rendering Life In Biopolitical Times. Minneapolis: University of Minnesota Press.

Singer, P. 1995 Animal Liberation, (2nd ed). London, Sydney and Auckland: Random House.

Somerville, M. 2000 The Ethical Canary: Science, Society and the Human Spirit. Middlesex: Penguin.

Sontag, S. 1991 Illness as Metaphor. Aids and its Metaphors (published in one volume). Middlesex: Penguin.

Sylvia, C. 1997 Change of Heart. New York: Little Brown and Company.

Takeuchi, Y. 2000 'Risk of zoonosis in xenotransplantation', Transplantation Proceedings, 32:2698-2700. 
Television Suisse Romanda, 2009 Remembering la Gloria (documentary). Retrieved July 13, 2011 from http://www.grain.org/articles/?id=58

The Wall Street Journal. 2009 ' 'Patient zero' in swine flu outbreak identified as 5 year old Mexican boy'. April 29. Retrieved June 8, 2011 from http://www. foxnews.com/story/o,2933,5/8347,0o.html.

Tuana, N. (ed) 1989 Feminism and Science, Bloomington and Indianapolis, Indiana University Press.

Tinker-Salas, M. 2009 Agri-biz at root of swine flu? Real news network report. Retrieved July 13, 2011, from http://links.org.au/node/1016

Uncaged Campaigns. Diaries of Despair: The secret history of pig to primate organ transplants. http://links.org.au/node/1016 Retrieved June 8, 2011 from http://www.xenodiaries.org/evidence.htm

Warren, J. 2004 'Xenotransplant news', Xenotransplantation, 11: 482-484.

Woods, T. 1998 'Have a heart: xenotransplantation, nonhuman death and human distress', Society and Animals, 6(1):47-65.

Wright, J.R. Jr. 2004 'Public consultation on xenotransplantation', Transplantation, 78:1112-1113. 